\title{
Wykorzystanie wiedzy i umiejętności zdobytych w Kole Naukowym Edukacji Międzykulturowej w pracy zawodowej absolwentów Wydziału Etnologii i Nauk o Edukacji Uniwersytetu Śląskiego
}

Streszczenie: Artykuł przedstawia powstanie i działalność Koła Naukowego Edukacji Międzykulturowej, organizacji studenckiej istniejącej od dziewięciu lat na cieszyńskim Wydziale Etnologii i Nauk o Edukacji Uniwersytetu Śląskiego w Katowicach. Udział studentów w konferencjach naukowych, projektach międzynarodowych i podejmowane przez nich inicjatywy pozwalają poszerzać wiedzę i zdobywać umiejętności społeczne (w tym międzykulturowe), organizacyjne, menedżerskie, a także naukowe. Okazują się one przydatne w dalszej pracy zawodowej, przez co wielu członków KNEM po studiach zostaje cenionymi przez pracodawców specjalistami.

Słowa kluczowe: organizacje studenckie, koła naukowe, samokształcenie

\section{Wprowadzenie}

Możliwość zrzeszania się w uczelnianych organizacjach studenckich jest jednym z podstawowych praw studentów zapisanych w Ustawie z dnia 27 lipca 2005 roku o Prawie o szkolnictwie wyższym ${ }^{1}$. Znajduje to odzwierciedlenie w regulaminach wewnętrznych uczelni ${ }^{2}$. Do takich organizacji należą: koła naukowe, zespoły artystyczne i sportowe, a także stowarzyszenia działające

1 Art. 4. Ustawy z dnia 27 lipca 2005 r. Prawo o szkolnictwie wyższym (Dz. U. nr 164, poz. 1365, z późn. zm.).

2 Np.: $\$$ 6., pkt 3. Regulaminu studiów w Uniwersytecie Śląskim. Załącznik do Uchwały nr 127 Senatu Uniwersytetu Śląskiego w Katowicach z dnia 24 kwietnia 2012 r.; $\$$ 10, pkt. 7-8 Regulaminu studiów Uniwersytetu w Białymstoku, Załącznik do Uchwały nr 1225 Senatu Uniwersytetu w Białymstoku z dnia 25 kwietnia 2012 r. 
w uczelniach. Ich działalność może być finansowana lub współfinansowana przez organy uczelni. Studenckie koła naukowe są miejscem rozwijania zainteresowań, poszerzania wiedzy, samokształcenia oraz zdobywania wielu cennych umiejętności.

Cieszyński Wydział Etnologii i Nauk o Edukacji Uniwersytetu Śląskiego w Katowicach od początku lat 90. XX wieku jest miejscem rozwoju edukacji międzykulturowej. Ukazująca się od 1992 roku pod redakcją Tadeusza Lewowickiego seria wydawnicza Edukacja Międzykulturowa liczy już 50 tomów. Tradycją stały się jesienne konferencje naukowe w Cieszynie i Ustroniu, w których uczestniczą badacze i praktycy edukacji międzykulturowej z całej Polski, a także z zagranicy. Jednocześnie od lat 90. cieszyńscy studenci pedagogiki realizują zagadnienia z zakresu wielokulturowości i międzykulturowości w ramach takich przedmiotów, jak: pedagogika ogólna, współczesne kierunki pedagogiczne, pedagogika porównawcza ${ }^{3}$. Od 2002 roku do programu studiów wybranych specjalności pedagogiki wpisane są przedmioty z zakresu edukacji wielo- i międzykulturowej.

Przytoczone powyżej fakty (wybrane spośród wielu innych i przedstawione bardzo skrótowo) świadczą o atmosferze budowanej przez pracowników naukowo-dydaktycznych Katedry, a później Zakładu Pedagogiki Ogólnej, na przestrzeni wielu lat. Powołanie studenckiego Koła Naukowego Edukacji Międzykulturowej (KNEM) w tak sprzyjających warunkach wydaje się rzeczą naturalną. Jak zwraca uwagę Alina Szczurek-Boruta, jedna z opiekunek naukowych KNEM, jego „działalność jest przedłużeniem, przejawem, a zarazem i pozytywnym efektem kształcenia w zakresie edukacji wieloi międzykulturowej"'.

\section{Powstanie i działalność Koła Naukowego Edukacji Międzykulturowej}

Koło Naukowe Edukacji Międzykulturowej zostało zarejestrowane w styczniu 2004 roku, lecz pierwsze spotkania grupy założycielskiej miały miejsce

3 A. Szczurek-Boruta: Szkolnictwo wyższe a teoria, modele badań i praktyka edukacji międzykulturowej. W: T. Lewowicki, E. Ogrodzka-Mazur, A. Szczurek-Boruta (red.): Edukacja międzykulturowa - dokonania, problemy, perspektywy. Cieszyn - Warszawa - Toruń 2011, Wydział Etnologii i Nauk o Edukacji Uniwersytetu Śląskiego, Wyższa Szkoła Pedagogiczna ZNP w Warszawie, Wydawnictwo Adam Marszałek, s. 177.

4 Tamże, s. 176-177. 
już w pod koniec poprzedniego roku, a ich tematyka nie koncentrowała się wyłącznie wokół spraw formalnych związanych z założeniem nowej organizacji studenckiej. W grudniu 2003 roku zaproszono Małgorzatę Kiereś, kierownika Muzeum Beskidzkiego w Wiśle, z gościnnym wykładem na temat pielęgnowania lokalnych tradycji bożonarodzeniowych, a także zorganizowano spotkanie opłatkowe integrujące jedenastoosobową grupę studentów pedagogiki z różnych lat i specjalności oraz opiekunki naukowe Koła - Alinę Szczurek-Borutę i Barbarę Grabowską.

Celem KNEM jest rozwijanie wiedzy i zainteresowań na temat edukacji międzykulturowej. Jest on realizowany poprzez następujące zadania:

- organizowanie sesji naukowych,

- uczestniczenie w konferencjach naukowych i seminariach,

- nawiązywanie współpracy z innymi kołami naukowymi zajmującymi się podobną tematyką na terenie całego kraju,

- prowadzenie badań naukowych ${ }^{5}$.

W początkowym okresie działalności młoda organizacja nie posiadała żadnych środków finansowych, niemniej jednak działała już dość prężnie. W styczniu 2004 roku dwie członkinie wybrały się do Milówki na Przegląd Zespołów Kolędniczych i Obrzędowych „Żywieckie Gody”. Później odbyły się spotkania z Anielą Różańską, Jolantą Suchodolską, ks. Janem Byrtem oraz ponowne spotkanie z Małgorzatą Kiereś. Poszerzane w ten sposób horyzonty i zagłębianie się w ideę międzykulturowości niewątpliwie wpłynęło na dalszą aktywność studentów.

W semestrze zimowym roku akademickiego 2004/2005 członkowie KNEM podejmowali wszystkie typy zadań, jakie wyznaczyli sobie w regulaminie:

- nawiązali współpracę z Kołem Naukowym Edukacji Międzykulturowej działającym na Wydziale Pedagogiki i Psychologii Uniwersytetu w Białymstoku;

- przeprowadzili cykl zajęć warsztatowych na temat tolerancji w szkołach podstawowych i gimnazjach w Cieszynie, Dębowcu, Radlinie i Suszcu;

- prowadzili badania sondażowe dotyczące postaw dzieci i młodzieży wobec szeroko rozumianej Inności;

- zorganizowali konferencję naukową pt. „Tolerancja - jak uczyć siebie i innych", w której wzięły udział przedstawicielki białostockiego Koła:

5 Regulamin KNEM, http://knem.us.edu.pl/index.php?option=com_content\&vi ew=article\&id=46\&Itemid=55 (21.01.2013). 
Emilia Ksepka i Agnieszka Sobocin. Co należy podkreślić - podczas konferencji zaprezentowano wyniki prowadzonych zespołowo badań sondażowych;

- wzięli udział w programie „Wielokulturowa Europa” organizowanym przez Instytut Europeistyki Uniwersytetu Jagiellońskiego w Krakowie we współpracy z British Council.

W pierwszym roku działalności utworzona została strona internetowa KNEM oraz logo przedstawiające wyciągnięte ku sobie ręce ludzi różnych ras na tle globu ziemskiego. Początkowe inicjatywy wiązały się z opanowaniem wielu zawiłości dotyczących funkcjonowania w przestrzeni finansowo-administracyjnej uczelni i podmiotów gospodarczych, z którymi Koło współpracowało, korzystając $\mathrm{z}$ ich usług, kupując potrzebne artykuły lub prosząc o sponsoring.

Do najstarszych tradycji KNEM należą imprezy andrzejkowe i mikołajkowe organizowane w przedszkolach, szkołach i placówkach opiekuńczo-wychowawczych. Zawsze miały one wymiar międzykulturowy. Już od dziewięciu lat studenci zachęcają dzieci do świadomego kultywowania tradycji regionalnych oraz przybliżają zwyczaje bożonarodzeniowe innych państw. Utrwaliła się również tradycja corocznych spotkań opłatkowych członków i opiekunów Koła, które pomagają budować atmosferę bliskości i zaufania w grupie.

W kształtowaniu klimatu organizacyjnego ${ }^{6}$ KNEM znaczącą rolę odgrywa sposób sprawowania opieki naukowej, który nie ogranicza spontanicznej aktywności studentów. Opiekunki nie narzucają kierunku i metod działań, lecz jedynie wspierają członków organizacji w realizacji celów - zarówno tych wpisanych do regulaminu, jak i indywidualnych aspiracji. Oznacza to pomoc w przechodzeniu od fazy pomysłu, poprzez projektowanie działań, aż po jego realizację i zakończenie.

Większość podejmowanych inicjatyw wymaga zaangażowania wielu osób, dlatego bardzo ważna jest umiejętność współpracy w grupie i pełnienia w niej różnych funkcji - osoba będąca koordynatorem jednego projektu, w innym jest odpowiedzialna za wybrane zadanie. Nastawienie członków Koła na współpracę, a nie na rywalizację, przekłada się na sposób funkcjonowania w środowisku akademickim. Część przedsięwzięć jest realizowanych wspólnie z innymi organizacjami studenckimi i jednostkami organizacyjnymi

6 G. Wudarzewski: Konceptualizacja pojęć „kultura organizacyjna” $i$ „klimat organizacyjny”. „Zeszyty Naukowe WSB we Wrocławiu” 2005, nr 5, s. 343. 
Wydziału. Czasami efekty współpracy znacznie przewyższają początkowe założenia inicjatorów, czego przykładem może być akcja „Cztery łapy w Twoich rękach", która miała być jednodniową konferencją naukową na temat dobrostanu zwierząt, a rozrosła się w ponadmiesięczny ciąg różnych imprez?

Aktualnie do KNEM należy prawie 30 osób. Liczba członków zmieniała się od chwili założenia organizacji, lecz nigdy jej działalność nie została zawieszona z powodu braku następców, co jest częstym problemem organizacji studenckich, wynikającym między innymi z krótszego niż dawniej okresu studiów. Intensywne i bardzo różnorodne działania studentów można ująć w sześciu obszarach aktywności:

1. organizowanie konferencji naukowych - często połączonych z towarzyszącymi wydarzeniami kulturalnymi (wystawy fotograficzne, pokazy filmów, imprezy tematyczne w klubie studenckim),

2. udział w konferencjach naukowych - przywilejem członków KNEM jest możliwość udziału we wspomnianych wcześniej jesiennych konferencjach w Cieszynie i Ustroniu, lecz uczestniczą oni również w sesjach naukowych w wielu innych ośrodkach akademickich (w Białymstoku, Krakowie, Raciborzu, Bielsku-Białej i in.),

3. udział w projektach międzynarodowych (np. polsko-litewski projekt „Trudne rozmowy o Czesławie Miłoszu - dialog, tolerancja, partnerska współpraca" finansowany przez Polsko-Litewski Fundusz Wymiany Młodzieży, polsko-litewsko-białoruskie warsztaty dla młodzieży we Wrocławiu i w Lipsku),

4. prowadzenie zajęć z zakresu edukacji wielo- i międzykulturowej w szkołach, przedszkolach i placówkach opiekuńczo-wychowawczych,

5. prowadzenie badań naukowych (np. badanie postaw studentów różnych uczelni i różnych kierunków wobec Amerykanów, Czechów, Francuzów, Romów i Żydów w ramach kilkuletniego projektu „Poznajmy Innego"),

6. organizowanie imprez charytatywnych na rzecz słabszych i potrzebujących.

Działalność w kole naukowym pozwala uzupełniać wiedzę zdobywaną podczas obligatoryjnych zajęć dydaktycznych, nabywać umiejętności praktyczne oraz kształtować charakter i światopogląd studenta. Od jego osobi-

7 Więcej nt. akcji: M. Milewska: Konferencja podsumowujaca akcje „Cztery tapy w Twoich rękach”, „Gazeta Codzienna” 9.01.2013, http://gazetacodzienna.pl/artykul/ kultura/konferencja-podsumowujaca-akcje-cztery-lapy-w-twoich-rkach (21.01.2013). 
stego zaangażowania zależy, na ile z możliwości tych skorzysta. Dziewięć lat działalności KNEM pozwala już wysnuć pewne wnioski na temat przydatności doświadczeń zdobytych w organizacji w pracy zawodowej absolwentów.

\section{Losy członków KNEM po ukończeniu studiów}

W latach 2004-2010 do KNEM należały łącznie 63 osoby (wg spisów zamieszczonych w kronice oraz na stronie internetowej $\left.{ }^{8}\right)$. Większość była związana z organizacją przez kilka lat. Prawie połowa pozostaje w kontakcie z opiekunkami i/lub byłymi członkami KNEM, co pozwoliło uzyskać informacje o ich rozwoju zawodowym.

Okres poszukiwania pracy po studiach był dla byłych członków Koła dość krótki (max. 6 miesięcy) lub nie występował wcale. Miejsca zatrudnienia większości absolwentów są zgodne z ich wykształceniem. Są to:

- ośrodki pomocy społecznej (praca w charakterze pracowników socjalnych),

- świetlica środowiskowa Caritas (wychowawca pełniący funkcję kierownika świetlicy),

- ognisko wychowawcze (w charakterze wychowawcy),

- warsztaty terapii zajęciowej (na stanowisku terapeuty),

- zakłady karne (w charakterze wychowawców),

- gminny ośrodek kultury (jako kierownik i choreograf zespołu regionalnego),

- szkoły wyższe (jako pracownicy naukowo-dydaktyczni),

- liceum (na stanowisku pedagoga szkolnego),

- gimnazjum (w charakterze sekretarki),

- szkoły podstawowe (jako nauczyciele edukacji wczesnoszkolnej),

- przedszkola - publiczne, prywatne oraz jedno prywatne przedszkole anglojęzyczne w Warszawie (jako nauczyciele wychowania przedszkolnego).

Pięć osób należących kiedyś do KNEM pisze aktualnie prace doktorskie trzy z nich są pracownikami uczelni, jedna wychowawcą w zakładzie karnym, jedna pracownikiem socjalnym. Trzy osoby po studiach wyjechały za granicę. Dwie prowadzą działalność prywatną. Dwie z własnej woli podjęły pracę w Polsce w zawodach innych niż wyuczony: jedna jest zatrudniona w zawodowej straży pożarnej, jedna w restauracji na stanowisku kierowniczym.

8 Strona KNEM: http://www.knem.us.edu.pl/ (21.01.2013). 
Absolwenci, którzy byli wcześniej aktywnymi członkami organizacji studenckich, mają większe doświadczenie w pracy z różnymi grupami wiekowymi u początku rozwoju zawodowego, przez co lepiej znają swoje predyspozycje i ograniczenia, a to z kolei pomaga im uniknąć przynajmniej niektórych porażek. Do umiejętności zdobywanych i doskonalonych w KNEM można zaliczyć:

- umiejętności organizacyjne - przechodzenie od fazy pomysłu, przez projekt, po jego realizację,

- umiejętności menedżerskie - zarządzanie zespołem ludzi oraz środkami finansowymi, które na ogół są niewystarczające, a sposób ich wydawania obwarowany wieloma przepisami,

- umiejętność pracy w zespole - odnajdywanie się zarówno w roli szatniarza, jak i prelegenta, rozumienie, że każda funkcja jest tak samo ważna dla sukcesu zespołu,

- umiejętność podejmowania wyzwań - mierzenie się nawet z bardzo trudnymi zadaniami i doprowadzanie ich do końca, udział w konkursach, pozyskiwanie funduszy na działalność spoza uczelni,

- umiejętności społeczne - efektywne prowadzenie rozmów z wieloma osobami, od których zależy powodzenie określonego przedsięwzięcia; rozumienie ich stanowiska, sztuka argumentacji, a także umiejętność radzenia sobie z bezpodstawnymi zarzutami,

- umiejętności naukowe - z pewnością większe niż u studentów, którzy nie działają w kołach naukowych, a przydatne nie tylko przyszłym doktorantom; prawidłowe przeprowadzenie badania socjometrycznego wśród uczniów lub zdiagnozowanie środowiska lokalnego przez ośrodek pomocy społecznej również wymaga takich umiejętności.

Najbardziej aktywni działacze organizacji studenckich (kilka członków KNEM należało jednocześnie do innych zrzeszeń) byli podczas studiów obciążeni wieloma dodatkowymi obowiązkami, które wynagradzała im własna satysfakcja i uznanie części środowiska. Kilka osób (wymienionych w tabeli 1) zostało wyróżnionych prestiżową nagrodą, jaką jest Stypendium Ministra Nauki i Szkolnictwa Wyższego, jednak zdecydowana większość (53 osoby) takiej nagrody nie otrzymała. Zastanawiać może wobec powyższego, czym kierują się studenci zapisujący się do Koła. Z potocznych rozmów prowadzonych podczas spotkań wynika, że większość zapisała się ze względów towarzyskich (namówiona przez dobrych znajomych) oraz dlatego, że w Kole działo się coś ciekawego. Nabywanie wiedzy i umiejętności poprzez dobro- 
wolne działanie może odbywać się w sposób nie do końca uświadomiony, lecz zawsze daje trwałe efekty. Pracodawcy cenią byłych członków KNEM za kreatywność i samodzielność, a oni sami nie obawiają się trudnych zadań (np. pisania projektów i rozliczania ich), z którymi nie raz przyszło im się zmierzyć już w trakcie studiów.

Tabela 1. Stypendyści ministra nauki i szkolnictwa wyższego należący do KNEM

\begin{tabular}{|l|l|l|}
\hline $\begin{array}{c}\text { Rok akademicki, w którym } \\
\text { przyznano stypendium }\end{array}$ & \multicolumn{1}{|c|}{ Imię i nazwisko } & Przynależność do organizacji studenckich \\
\hline \multirow{2}{*}{$2005 / 2006$} & Katarzyna Jas & KNEM \\
\cline { 2 - 3 } $2007 / 2008$ & Magdalena Książek & KNEM \\
\hline \multirow{2}{*}{$2008 / 2009$} & Aleksandra Gancarz & KNEM \\
\cline { 2 - 3 } & Katarzyna Gebel & KNEM \\
\cline { 2 - 3 } & Agnieszka Gozdek & KNEM \\
\hline \multirow{2}{*}{$2009 / 2010$} & Irena Foks & KNEM \\
\cline { 2 - 3 } & Justyna Jabłeka & KNEM \\
\cline { 2 - 3 } & Karolina Kania & $\begin{array}{l}\text { KNEM, } \\
\text { Studenckie Koło Naukowe Etnologów, Mię- } \\
\text { dzywydziałowy Zespół Folkowy „FolkUŚ” }\end{array}$ \\
\cline { 2 - 3 } & Sabina Kamińska & $\begin{array}{l}\text { KNEM } \\
\text { Studenckie Koło Naukowe Zintegrowanej } \\
\text { Edukacji Wczesnoszkolnej }\end{array}$ \\
\cline { 2 - 3 } & Monika Michalak & $\begin{array}{l}\text { KNEM } \\
\text { Studenckie Koło Naukowe Zintegrowanej } \\
\text { Edukacji Wczesnoszkolnej }\end{array}$ \\
\hline
\end{tabular}

\section{Zakończenie}

Działalność w organizacji studenckiej ma mnóstwo zalet, lecz mimo to wciąż niewielki odsetek ogółu wszystkich studentów decyduje się na ten krok. Ożywienie w tej dziedzinie przyniosły zmiany w sposobie przyznawania stypendiów. Odkąd stypendium naukowe przyznawane wyłącznie na podstawie średniej arytmetycznej ocen zastąpiono przez stypendium rektora, którego kryteria poszerzono o osiągnięcia naukowe ${ }^{9}$, liczba członków organizacji studenckich wzrosła. Formalne i nieformalne grupy żaków organizują od 2012 roku zdecydowanie więcej konferencji naukowych, problemem jednak jest to, że czasami stwarzają one tylko pozory rzeczywistej, spontanicznej ak-

$9 \mathbb{\$} 19$, ust. 1. pkt. 6. Regulaminu ustalania wysokości, przyznawania i wypłacania świadczeń pomocy materialnej dla studentów Uniwersytetu Śląskiego, Załącznik nr 3 do zarządzenia nr 99 Rektora UŚ z dnia 3 sierpnia 2012 r. 
tywności studentów, która wynikałaby z ich autentycznej ciekawości poznawczej. Instrumentalne podejście do działalności w kołach naukowych zabija ich najgłębszą ideę zorientowaną - w moim przekonaniu - na autoteliczność kształcenia i samorozwoju. Wprawdzie nowelizacja ustawy o szkolnictwie wyższym oddaliła widmo tzw. luki pokoleniowej grożącej przerwaniem ciągłości organizacji, lecz obecna sytuacja stawia opiekunom nowe zadania. Wśród studentów zapisujących się dziś do kół naukowych są zarówno pasjonaci wiedzy, jak i ludzie walczący o stypendialne laury, nadrabiający niekiedy bylejakość działań ich liczbą. Zadaniem opiekuna naukowego jest w tej sytuacji wydobywanie tego, co najlepsze ze studentów instrumentalnie nastawionych do kół naukowych, wiara w możliwość zmiany ich nastawienia oraz nadzieja, że kiedyś zdobywanie wiedzy i umiejętności będzie dla nich taką samą przyjemnością jak dla pasjonatów. Wiara w człowieka i nadzieja na pozytywną zmianę nie powinny opuszczać pedagogów, ponieważ - jak pisze Marek Rembierz: „Jeśli doświadcza się w pedagogice braku nadziei, to wzmagają się wówczas bierność i apatia, wręcz marazm, bowiem ludzi zaczyna się postrzegać jedynie jako »beznadziejne przypadki«, które nie rokują jakiejkolwiek poprawy. Stan beznadziei unicestwia sensowną teorię i praktykę pedagogiczną"

\section{Bibliografia}

Milewska M.: Konferencja podsumowujaca akcje „Cztery tapy w Twoich rękach”. „Gazeta Codzienna” 9.01.2013, http://gazetacodzienna.pl/artykul/ kultura/konferencja-podsumowujaca-akcje-cztery-lapy-w-twoich-rkach (21.01.2013).

Regulamin KNEM http://knem.us.edu.pl/index.php?option=com_content\& view $=$ article\&id $=46 \&$ Itemid $=55$ (21.01.2013).

Regulamin studiów Uniwersytetu w Białymstoku, Załącznik do Uchwały nr 1225 Senatu Uniwersytetu w Białymstoku z dnia 25 kwietnia 2012 r. Regulamin studiów w Uniwersytecie Śląskim, Załącznik do Uchwały nr 127

Senatu Uniwersytetu Śląskiego w Katowicach z dnia 24 kwietnia 2012 r. Regulamin ustalania wysokości, przyznawania i wypłacania świadczeń po-

10 M. Rembierz: Bezradność i samodzielność jako kategorie pedagogiczne. Od rozpoznania patologii do kształtowania podmiotowości. „Roczniki Pedagogiczne” 2009, t. 1 (37), s. 103-104. 
mocy materialnej dla studentów Uniwersytetu Śląskiego, Załącznik nr 3 do zarządzenia nr 99 Rektora UŚ z dnia 3 sierpnia 2012 r.

Rembierz M.: Bezradność i samodzielność jako kategorie pedagogiczne. Od rozpoznania patologii do kształtowania podmiotowości. „Roczniki Pedagogiczne" 2009, t. 1 (37).

Strona KNEM: http://www.knem.us.edu.pl/ (21.01.2013).

Szczurek-Boruta A.: Szkolnictwo wyższe a teoria, modele badań i praktyka edukacji międzykulturowej. W: T. Lewowicki, E. Ogrodzka-Mazur, A. Szczurek-Boruta (red.): Edukacja międzykulturowa - dokonania, problemy, perspektywy. Cieszyn - Warszawa - Toruń 2011, Wydział Etnologii i Nauk o Edukacji Uniwersytetu Śląskiego, Wyższa Szkoła Pedagogiczna ZNP w Warszawie, Wydawnictwo Adam Marszałek.

Ustawa z dnia 27 lipca 2005 r. Prawo o szkolnictwie wyższym (Dz. U. nr 164, poz. 1365, z późn. zm.).

Wudarzewski G.: Konceptualizacja pojęć „kultura organizacyjna” $i$ „klimat organizacyjny”. „Zeszyty Naukowe WSB we Wrocławiu” 2005, nr 5.

\section{Application of the knowledge and skills acquired in the Science Club of Intercultural Education in professional work of the graduates of the Faculty of Ethnology and Education at the University of Silesia}

\section{Summary}

The article presents the foundation and activity of the Science Club of Intercultural Education, a students' organization which has existed for nine years at the Faculty of Ethnology and Education of the University of Silesia in Katowice. Students' participation in academic conferences or international projects and the initiatives which they undertake allow for broadening the knowledge and for acquiring social (also intercultural), organizational, managing and scientific skills. They turn out to be useful in further professional career, therefore after graduation many club members become specialists who are highly valued by employers.

Key words: student organizations, science clubs, self-education 